\title{
Pendampingan Les Tambahan Matapelajaran Matematika Di Taman Baca Gracia, Melalui Bimbingan Belajar Peserta Didik Di Kelurahan Prailiu
}

\author{
Roslin Paji Jera $^{1 *}$, Jumaspan Umbu Wuri ${ }^{2}$, Angelita Doke Koro ${ }^{3}$, Sely Jera Umaratu ${ }^{4}$, \\ Febiana Kesia Bili ${ }^{5}$, Jandri Christofel Radjah ${ }^{6}$, Cristin L. Wibe ${ }^{7}$, Junior Sommer Juru \\ Mbaha $^{8}$, Arlon Kahendu ${ }^{9}$, Elliana Marthila Lemba Roboth ${ }^{10}$, Nino Nicholas ${ }^{11}$, \\ Wehelmina Mone ${ }^{12}$, Valentania Rambu Nora ${ }^{13}$, Yumitha Valerie Rambu Mburu ${ }^{14}$, \\ Novriani Kariri Ngadang ${ }^{15}$, Adrianus H. L. Amah ${ }^{16}$, Astry Lestari Lado ${ }^{17}$ \\ Universitas Kristen Wira Wacana Sumba: Jln, R Suprapto No. 35 Waingapu, telp: \\ 123456789, fax:123456789urusan/Program Studi Pendidikan Matematematika, Fakultas \\ Ilmu-Ilmu Sosial \\ Program Studi Pendidikan Matematika, Universitas Kristen Wira Wacana Sumba \\ *email: roslinpajijeraera22@gmail.com
}

Informasi Artikel

Diterima Redaksi : 26 Juni 2020

Revisi Akhir : 23 September 2020

Diterbitkan Online: 26 Oktober 2020

Kata Kunci:

(Maksimal 5 Kata Kunci dan disusun sesuai urutan huruf abjad setiap awalan huruf kata kunci)

\begin{abstract}
Abstrak
Pelaksanaan kegiatan pendampingan belajar di taman baca Gracia merupakan bentuk pengabdian kepada masyarakat yang hal ini dilaksanakan oleh mahasiswa himpunan GAMMA program Stuidi Pendidikan Matematika Unkriswina. Dengan adanya bimbingan belajar peserta didik sangat terbantu dalam memahami matapelajaran matematika dengan meningkatkan prestasi belajar di Sekolah terselenggaranya kegiatan ini karena faktor pelaksanaan pembelajaran di sekolah belum cukup untuk memberi pemahaman yang baik bagi peserta didik. Metode yang digunakan adalah memberikan bimbingan belajar matematika kepada peserta didik dari kelas 3 SD-SMP kegiatan pelaksanaan Pengabdian masyarakat dilaksanakan selama satu bulan lebih. Hasil yang diperoleh adalah adanya peningkatan prestasi belajar siswa di Sekolah. Adapun yang menjadi harapan penulis adalah diperlukan dukungan pemerintah, masyarakat dalam meningkatkan kualitas pendampingan belajar melalui bimbingan yaitu berupa pemenuhan fasilitas karena kurangnya ruangan di taman baca Gracia.

Kata Kunci: Pendampingan, bimbinbingan,belajar, matematika
\end{abstract}

\section{PENDAHULUAN}

Pendidikan merupakan suatu wadah yang memberikan suatu pengajaran kepada peserta didik dari yang tidak tahu menjadi tahu dengan tujuan untuk meningkatkan bakat minat peserta didik. Dengan mengacu pada tujuan pendidikan nasional UU No.20 tahun 2003 tentang Sisdiknas seperti yang tertulis pada pasal 13 ayat (1) "Jalur pendidikan terdiri atas pendidikan formal, nonformal, dan informal yang dapat saling melengkapi dan memperkaya".

Tujuan matapelajaran matematika merupakan suatu yang perlu diterapkan pada pembelajaran ditingkat sekolah baik dari tingkat bawah, pertengahan sampai pada tingkat atas (Sutawidjaja, dkk.2014). Sedangkan menurut Amir, dkk (2016) matematika adalah kegiatan yang dilakukan manusia yang terkandung pola pikir yang logis yang dinyatakan dalam bilangan, ruang, dan bentuk-bentuk serta aturan-aturan. Hal ini perlu dipelajari karena matematika hadir dalam setiap aktivitas manusia yang mengikat aturanaturan berpikir dalam bentuk, ruang dan bilangan. Kegiatan mendeskripsikan atau memodelkan beberapa kajian teori atau 
memformulasikan rumus kedalam

kehidupan nyata disebut sebagai matematika terapan (Iswanto. 2019:9). Oleh sebab itu matematika sangat berperan penting dalam kehidupan sehari-hari sebagai matematika terapan yang artinya bahwa matematika merupakan sesuatu perwujudan dari alam atau lingkungan sekitar.

Prestasi belajar matematika di Sumba Timur masih sangat jauh di bawah rata-rata saat ini. Menurut Aisyah (2014) prestasi belajar adalah proses belajar mengajar yang diperoleh peserta didik dengan adanya pencapaian hasil dengan mengikuti tes serta memperoleh skor nilai. Agar prestasi belajar peserta didik terjadi peningkatan diperlukan bimbingan belajar sehingga peserta didik mendapatkan fungsi pemeliharaan dan pengembangan dalam belajar.

Berdasarkan hasil observasi serta wawancara dengan peserta didik di taman baca Gracia pada tanggal 17 November 2019, bahwa prestasi belajar mereka masih sangat kurang khususnya dalam matapelajaran matematika dilihat dari laporan hasil belajar yang terima dari sekolah. Dengan demikian peserta didik mempunyai motivasi untuk mengikuti bimbingan belajar matematika demi meningkatkan prestasi belajar dalam matapelajaran matematika dan mengharapkan adanya bantuan bimbingan belajar matematika dari salah satu instansi profesi matematika. Bimbingan belajar merupakan wadah untuk mengembangkan suasana belajar yang kondusif serta meningkatkan kecerdasan, karena adanya hal-hal yang menunjukkan kesulitan, kegagalan, dan tidak mendapatkan bimbingan belajar yang optimal yang dialami peserta didik. Penerapan bimbingan belajar adalah salah satu cara dalam mengatasi kesulitan belajar, meningkatkan pemahaman bakat minat kepada bidang tertentu, menyiapkan diri untuk mengerjakan tugas atau ujian serta menanamkan sikap percaya diri pada peserta didik di sekolah dalam menempuh pendidikan selanjutnya (Fiah, dkk.2016).

Matematika sangat berperan penting dalam kehidupan sehari-hari serta peran dalam peningkatan kualitas sumber daya manusia secara umumnya. Peran matematika dalam meningkatkan sumber daya manusia yaitu mampu memberikan pemahaman dalam suatu kejadian, menyelesaikan suatu masalah dengan cara terurut atau sistematis serta dengan secara jelas memacu untuk berpikir secara real dan konsisten (Widodo. 2018).

Dengan adanya masalah Himpunan Gerakan Mahasiswa Matematika (GAMMA) Program Studi Matematika Universitas Kristen Wira Wacana Sumba bertindak untuk melaksanakan kegiatan Pengabdian Kepada Masyarakat (PKM), untuk meningkatkan prestasi belajar matematika di Sekolah serta memenuhi kurangnya pendampingan belajar bagi peserta didik diluar jam sekolah.

\section{METODE PENELITIAN}

Pelaksanaan kegiatan bertempat di Taman Baca Gracia Jl. J. Tatatengkeng No. 1 Tandarotu Waingapu Kelurahan Prailiu Kecamatan Kambera Kabupaten Sumba Timur, pada tanggal 27 November 2019-04 Januari 2020. Subyek dalam penelitian ini adalah peserta didik SD kelas 3 -SMP yang mengalami rendahnya prestasi belajar matematika di sekolah yang menjadi guru pendamping dalam bimbingan belajar adalah Mahasiswa program Studi Pendidikan Matematika Unkriswina.

\section{HASIL DAN PEMBAHASAN}

Pelaksananan kegiatan pendampingan les tambahan bimbingan belajar dilaksanakan dalam seminggu dua kali pada hari kamis dan sabtu, dengan lama waktu belajar dalam sekali pertemuan 2 jam. Pendampingan belajar dilakukan dengan peserta didik menjelaskan kesulitan belajar yang mereka hadapi saat belajar di sekolah saat belajar matematika, kemudian mahasiswa Unkriswina Program Studi Pendidikan Matematika Himpunan Gerakan Mahasiswa Matematika (GAMMA) membantu untuk menyelesaikan kesulitan yang peserta didik hadapi. Dengan cara memberikan penjelasan ulang dengan secara sederhana, dengan disertai pemberian contoh soal untuk dikerjakan peserta didik. Serta sebelum memulai kegiatan diawali dengan doa dan juga diakhir kegiatan melakukan doa bersama. 
Adapun kendala yang dihadapi yaitu keterbatasan ruangan belajar, di karenakan banyak peserta didik yang ikut serta dalam pendampingan belajar, karena daya juang peserta didik sangat tinggi dalam belajar matematika. Menurut Amir, dkk (2016:177) daya juang sangat mempengaruhi prestasi belajar matematika peserta didik contohnya mendapatkan nilai yang memuaskan khususnya dalam belajar matematika, terbentuknya sikap kedisiplinan yang menghargai waktu karena dalam matematika mengajarkkan atau menanamkan sikap kedisiplinan dalam kegiatan. Dalam progres kegiatan Pengabdian Kepada Masyarakat yang dilakukan oleh Mahasiswa (GAMMA) mendapatkan suatu ungkapan dari peserta didik bahwa adanya pendampingan belajar sangat menambah pemahaman terhadap materi matematika sehingga dalam pelaksanaan belajar di sekolah mengalami kemudahan.

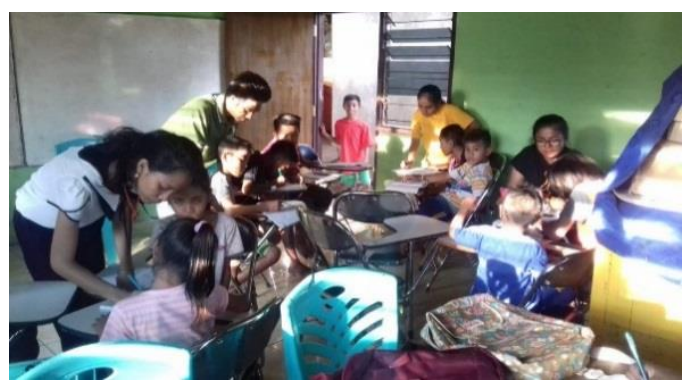

Gambar 1. Peserta didik mengemukakan bagian materi yang dianggapnya sulit

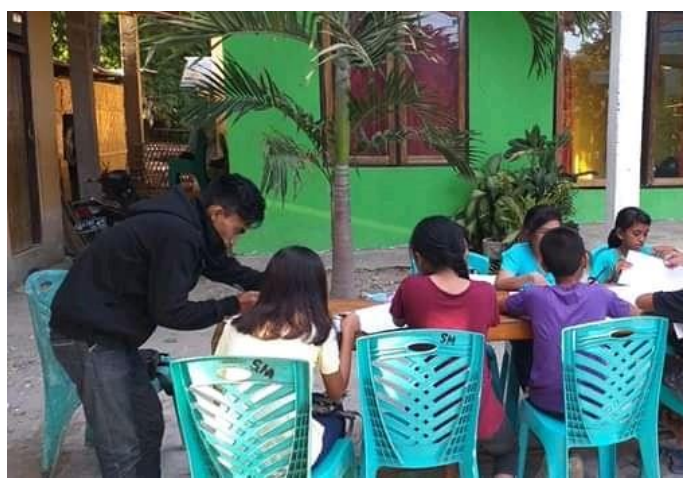

Gambar 2. Pelaksanaan bimbingan diluar ruangan

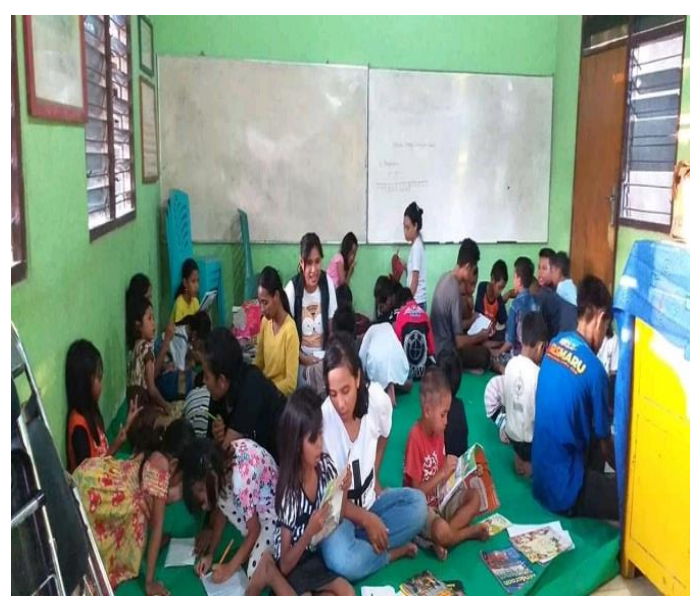

Gambar 3. Mahasiswa menjelaskan bagian materi matematika yang dianggap sulit oleh peserta didik.

\section{KESIMPULAN}

Kegiatan Pengabdian kepada Masyarakat dilakukan dengan memberikan solusi terhadap kesulitan yang dialami peserta didik di sekolah, serta memberikan contoh soal untuk lebih melatih kemampuan belajar peserta didik. Peserta didik mengalami peningkatan prestasi belajar matematika di sekolah saat mendapatkan pendampingan belajar dari Mahasiswa (GAMMA).

\section{SARAN}

Adapun yang menjadi saran penulis yaitu dalam mewujudkan peningkatan sumber daya manusia di bangsa Indonesia sangat diperlukan pendampingan belajar dengan didukung fasilitas yang baik sehingga mendapatkan kenyamanan dalam tercapainya kegiatan belajar. Dengan demikian menjadi keprihatinan bersama baik pemerintah, masyarakat dalam mengadakan fasilitas pendidikan. Dan juga diperlukan dorongan dari orangtua dalam mendukung keikutasertaan peserta didik dalam pendampingan belajar demi meningkatkan prestasi belajar matapelajaran matematika di sekolah.

Saran penulis kepada pembimbing adalah diperlukan suatu kesiapan yang baik dalam melaksanakan kegiatan sehingga pelakasanaan kegiatan pengabdian kepada 
masyarakat pada tahap berikutnya dapat terlaksana dengan baik.

\section{UCAPAN TERIMA KASIH}

Ucapan terima kasih kepada Kepala Program studi Pendidikan Matematika, kepada dekan Fakultas Ilmu-Ilmu Sosial yang telah menyetujui pelaksanaan kegiatan Pengabdian Kepada Masyarakat. Terimakasih juga kepada Ibu Solvina Malahina S.Pd selaku koordinator taman baca Gracia yang memberi persetujuan dalam pelaksanaan Pengabdian Kepada masyarkat. Ucapan terimakasih yang terakhir adalah kepada teman-teman mahasiswa program studi Pendidikan Matematika Unkriswina yang telah memberi atau berbagi pengetahuan dalam memberi pendampingan belajar terhadap peserta didik.

\section{REFERENSI}

[1] Sutawidjaja, A., \& Dahlan, J. A. (2014). Pembelajaran matematika.

http://repository.ut.ac.id/4377/1/MP MT5301-M1.pdf

[2] Amir, dkk. 2016.Psikologi Pembelajaran Matematika.Aswaja pressindo:Yogyakata

[3] Aisyah, E.2014. Perbandingan Prestasi Belajar Matematika antara yang mendapatlan model active learning tipe Giving Question And Getting Answer dengan Konvendional. Jurnal Pendidikan Matematika Volume 3 Nomor 1.

[4] Fiah, dkk.2016. Penerapan Bimbingan belajar dalam meningkatkan hasil belajar peserta didik di SMP Negeri 12 Kota Bandar Lampung Tahun pelajaran 2015/2016. Jurnal Bimbingan dan Konseling. Volumme 03 Nomor 2.

[5] Widodo. 2018. Peran Matematika dan memajukan Sumber daya manusia
(SDM) Guna Membangun Bangsa.

Jurnal Peran Matematika Dalam pembangunan SDM .Yogyakarta 17 Februari 2018. 